\title{
Swimming speed of three species of Alexandrium (Dinophyceae) as determined by digital in-line holography
}

\author{
Nancy I. Lewis ${ }^{1 *}$, Wenbo Xu², Stefan K. Jericho ${ }^{2}$, Hans J. Kreuzer ${ }^{2}$, Manfred H. Jericho ${ }^{2}$ And Allan D. Cembella ${ }^{1,3}$ \\ ${ }^{1}$ Institute for Marine Biosciences, National Research Council, Halifax, Nova Scotia B3H 3Z1, Canada \\ ${ }^{2}$ Department of Physics and Atmospheric Science, Dalhousie University, Halifax, Nova Scotia B3H 3J5, Canada \\ ${ }^{3}$ Alfred Wegener Institute for Polar and Marine Research, Am Handelshafen 12, D-27570 Bremerhaven, Germany
}

\begin{abstract}
N.I. Lewis, W. Xu, S.K. Jericho, H.J. Kreuzer, M.H. Jericho and A.D. Cembella. 2006. Swimming speed of three species of Alexandrium (Dinophyceae) as determined by digital in-line holography. Phycologia 45: 61-70. DOI: 10.2216/04-59.1

Digital in-line holographic (DIH) microscopy was used to track motility in several related species of the marine dinoflagellate Alexandrium in response to temperature after acclimation at selected temperatures. Numerical reconstruction of DIH holograms yielded high-contrast three-dimensional images of the trajectories of many motile cells swimming simultaneously throughout the sample volume. Swimming speed and trajectory were determined for clonal isolates of A. ostenfeldii, A. minutum and $A$. tamarense within the temperature range from 8 to $24^{\circ} \mathrm{C}$. The strains of these species revealed differences in temperature optima for growth and tolerance that were a function of both acclimation responses and genetic factors reflecting the origin of the isolates. The fastest swimming speeds were recorded at $24^{\circ} \mathrm{C}$ for cells of A. minutum. Acclimated strains of all three species swam significantly slower at lower temperatures, although fastest swimming speeds did not always occur at temperature optima for growth. Aged cells from stationary phase cultures swam more slowly than cells in exponential growth phase. Doublets from a rapidly dividing culture swam faster than singlets from the same culture, confirming the propulsive advantage of paired cells. Holographic microscopy is a powerful tool for the acquisition of detailed observations of swimming behaviour of microalgal cells in the form of three-dimensional trajectories over the appropriate temporal (sub-second) and spatial (micrometer) scales.
\end{abstract}

KeY WoRDS: Alexandrium, growth, holography, motility, temperature

\section{INTRODUCTION}

The dinoflagellate Alexandrium (Halim) Balech has been extensively studied, particularly with respect to the capacity of many species of this genus to produce potent neurotoxins associated with paralytic shellfish poisoning (Cembella 1998). However, very little is known about the details of swimming behaviour in this genus even though vertical migration and sinking are undoubtedly important nutrient acquisition (MacIntyre et al. 1997) and life-history (Anderson 1998) strategies. Swimming, widespread among pelagic dinoflagellates, conveys ecophysiological benefits to the flagellates, e.g. prey capture, escape from predation, and taxis for optimization of the light field and for acquisition of inorganic nutrients. A cost-benefit analysis (Raven \& Richardson 1984) showed that the benefits of migration could substantially exceed the bioenergetic costs to the dinophyte cell, which uses only a fraction of the energy available for motility. Previous classic studies of swimming behaviour have explored the functions of phototaxis (Forward 1974; Hand \& Schmidt 1975) and diel vertical migration, which may provide a competitive advantage to these bloom-forming dinoflagellates (Eppley et al. 1968).

This genus exhibits a typical dinokont arrangement, whereby propulsion is accomplished by means of two flagella - a posteriorly directed trailing flagellum and a transverse or ribbon flagellum. The trailing flagellum is associated with the sulcus, a longitudinally oriented groove on the ventral side of

*Corresponding author (nancy.lewis@nrc-cnrc.gc.ca). the cell, whereas the ribbon flagellum is attached along the proximal margin and is located within the cingulum (girdle) encircling the cell. The form and function of the transverse flagellum have been documented (Leblond \& Taylor 1976; Gaines \& Taylor 1985), and the mechanism of propulsion is well explained, but can differ among dinokont species (Goldstein 1992). The movement of the ribbon flagellum causes the cell to rotate and move in a forward direction ("propeller"), while the trailing flagellum controls the direction of movement ("rudder") (Gaines \& Taylor 1985), in addition to providing some forward propulsion (Hand \& Schmidt 1975). When the trailing flagellum of some dinoflagellates is lost through mechanical damage or other stress, the cell loses control of its forward momentum and begins swimming erratically (F.J.R. Taylor, personal communication).

As described by Kamykowski (1995), swimming behaviour in dinoflagellates can be separated into two components speed and orientation. Swimming ability varies widely among flagellated species, even among those with similar morphology, and little is known how it may be affected by environmental and genetic factors. Dinoflagellates are some of the fastest swimmers among the phytoflagellates (Raven \& Richardson 1984), with typical swimming speeds up to 300-600 $\mu \mathrm{m}^{-1}$ (Levandowsky \& Kaneta 1987). The instantaneous swimming speed of dinoflagellates is directly influenced by a host of environmental factors, including turbulence, gravity, temperature, photon flux density, salinity, dissolved oxygen concentration and inorganic nutrients (see Kamykowski et al. 1998 and references cited therein) and, to a certain extent, by 
Table 1. The mean cell length and swimming speed $( \pm s)$ and range of swimming speeds for each species of Alexandrium measured at different acclimated temperatures. $F$ values determined by one-way ANOVA (SigmaStat, V.2.03, SPSS Science).

\begin{tabular}{|c|c|c|c|c|c|c|c|}
\hline \multirow[b]{2}{*}{ Species } & \multirow{2}{*}{$\begin{array}{l}\text { Length }(\mu \mathrm{m}) \\
\quad(\bar{x} \pm s)\end{array}$} & \multicolumn{5}{|c|}{ Swimming speed $\left(\mu \mathrm{m} \mathrm{s}^{-1}\right)$ range $(\bar{x} \pm s)$} & \multirow[b]{2}{*}{$F$} \\
\hline & & $8^{\circ} \mathrm{C}$ & $12^{\circ} \mathrm{C}$ & $16^{\circ} \mathrm{C}$ & $20^{\circ} \mathrm{C}$ & $24^{\circ} \mathrm{C}$ & \\
\hline A. ostenfeldii & $41.1 \pm 4.5$ & $\begin{array}{c}29-187 \\
(117 \pm 34) \\
n=31\end{array}$ & $\begin{array}{c}31-112 \\
(66 \pm 19) \\
n=20\end{array}$ & $\begin{array}{c}73-227 \\
(150 \pm 34) \\
n=16\end{array}$ & $\begin{array}{c}82-160 \\
(114 \pm 23) \\
n=19\end{array}$ & & $27 *$ \\
\hline A. tamarense & $26.7 \pm 2.6$ & $\begin{array}{c}80-201 \\
(124 \pm 25) \\
n=30\end{array}$ & $\begin{array}{c}42-194 \\
(108 \pm 44) \\
n=11\end{array}$ & $\begin{array}{c}70-266 \\
(200 \pm 40) \\
n=18\end{array}$ & $\begin{array}{c}38-249 \\
(120 \pm 49) \\
n=30\end{array}$ & $\begin{array}{c}129-406 \\
(255 \pm 81) \\
n=24\end{array}$ & $33 *$ \\
\hline
\end{tabular}

* Indicates differences in swimming speed are significant for $p<0.001$.

physical characteristics of the cell, such as size (Kamykowski \& McCollum 1986) and morphology (Roberts 1981).

Dinoflagellate motility is affected by the temperature at which cells are acclimated and this effect is species specific (Kamykowski \& McCollum 1986; Lewis et al. 2003). Temperature shifts can lead to modified swimming behaviour but not necessarily loss of motility. The effect of environmental factors such as temperature on motility has implications for natural populations of dinoflagellates where the ability of a cell to move away from adverse conditions toward a more favourable environment potentially affects bloom formation.

Tracking and recording the trajectories of particles, such as microscopic flagellates, moving through three-dimensional space has been a challenge. An early attempt to obtain accurate velocity measurements of the dinoflagellates Lingulodinium polyedrum (Stein) Dodge (= Gonyaulax polyedra) and an unidentified species of Gyrodinium Kofoid \& Swezy with respect to effects of changes in temperature and salinity was made with an electronic tracking system (Hand et al. 1965). Most previous studies of movement in dinoflagellates used conventional compound microscopy and video cameras to record the motion of cells. Although it is possible to track swimming cells in a single plane of focus using video cameras with sophisticated image analysis systems, recording and quantifying the motion of algal cells in three-dimensional space is complex. Conventional microscopy can effectively capture motion only in two dimensions because of limited depth of field. Calculations of algal swimming speeds are thus difficult because of the movement of the cells through many focal planes. Nevertheless, there have been a few successful attempts. Iken et al. (2001) used a CCD video camera attached to a compound microscope to quantify movement of spores of the phaeophyte Hincksia irregularis (Kützing) Amsler.

In this study we used digital in-line holography (DIH) to simultaneously track the motion in three dimensions and in subsecond time of three morphologically similar species of Alexandrium that differ in size. This technique was first used to study the swimming behaviour of the chlorophyte Tetraselmis Stein in culture (Xu et al. 2003). The advent of DIH technology presented an opportunity to look more closely at the movement of phytoflagellates, such as the dinoflagellate genus Alexandrium, known to respond to environmental cues. Results showed that the swimming behaviour of Alexandrium was affected by exposure to different (nonlethal) temperatures following acclimation, and that the response was species- if not strain-specific.

\section{MATERIAL AND METHODS}

\section{Collection and maintenance of isolates}

Isolates of three species of Alexandrium differing in size and optimal temperature requirements for growth were chosen for the study. Motile cells were photographed at $\times 200$ magnification using a Leica DMRE light microscope and measurements of cell diameter were made using Simple PCI Compix image analysis software (Table 1). A one-way ANOVA performed on cell length showed the three isolates differed significantly in size $\left(P<0.001, F_{2,87}=302\right.$, Tukey's post hoc, $P<0.05$ ). The largest isolate, A. ostenfeldii (Paulsen) Balech \& Tangen clone AOSH1, was isolated in late spring 1998 from Ship Harbour, an estuarine fjord in Nova Scotia, Canada, from a size-fractionated plankton sample collected by pumping at 3-m depth. Alexandrium tamarense (Lebour) Balech clone SB50 was isolated from Shelburne Harbour, on the southeastern shore of Nova Scotia, also from a size-fractioned pump sample collected at 3-m depth in late spring 2000. Alexandrium minutum Halim clone AMAD-06 was germinated from a cyst collected from sediments in Port River, South Australia, in 1987.

\section{Temperature-dependent growth experiments}

Experiments were carried out to determine the range of temperature over which optimal growth of the isolates occurred under defined conditions. Unialgal stock cultures were grown in L1 enriched-seawater medium (Guillard \& Hargraves 1993). Borosilicate glass culture tubes $(50 \mathrm{ml})$ containing 25 $\mathrm{ml}$ of L1 growth medium were inoculated in replicates of three, with $5 \mathrm{ml}$ of exponentially growing cultures. Cultures were incubated under an ambient photon flux density of 125 $\mu \mathrm{mol}$ photons $\mathrm{m}^{-2} \mathrm{~s}^{-1}$ of cool-white fluorescent light on a 14 : $10 \mathrm{~h}$ light : dark photocycle at $8,12,16,20$ and $24^{\circ} \mathrm{C}$. Tubes were rotated every second day to account for slight differences in photon flux density at each position in the rack. Cell concentrations were estimated by in vivo fluorescence, using a Turner Designs fluorometer equipped with a filter set optimized for chlorophyll $a$, which has been shown to be a valid 
method for measuring dinoflagellate growth rate based upon relative fluorescence for both $A$. tamarense (Parkhill \& Cembella 1999) and A. ostenfeldii (MacLean et al. 2003). Fluorometer readings were taken every two days at the same point in the photocycle, two $\mathrm{h}$ after the beginning of the light period. Culture tubes were gently inverted four times to resuspend cells and to create a homogenous distribution before readings were taken.

\section{Swimming speed determination by DIH microscopy}

Cells in exponential growth phase were preconditioned in 30 $\mathrm{ml}$ of $\mathrm{L} 1$ medium in 20 by $60 \mathrm{~mm}$ Petri dishes for 2-3 days at each experimental temperature $\left(8,12,16,20\right.$ and $\left.24^{\circ} \mathrm{C}\right)$ under the above irradiance conditions. The small plastic dishes permitted easy access to cultures during the experiment. Movement of "aged" cells from 32 day old stationary phase cultures of A. minutum was also observed at 8 and $24^{\circ} \mathrm{C}$. A comparison of exponential vs stationary phase at the two temperature extremes was not carried out for the other two species because after 32 days there was no sign of motile cells at $24^{\circ} \mathrm{C}$.

For measurements of swimming speed, the algal suspension was placed in a $1 \times 15 \times 25 \mathrm{~mm}$ glass chamber constructed from microscope slides and a cover slip with light propagation along the shortest dimension. Temperature in the medium was monitored with a type-K thermocouple attached to the chamber. Samples were changed after $10 \mathrm{~min}$ to ensure that the temperature in the chamber did not vary by more than $1{ }^{\circ} \mathrm{C}$. The chamber was cleaned between samples by washing three times with $100 \%$ ethanol and three times with temperatureequilibrated culture medium.

When cell concentration was high enough to potentially affect swimming behaviour, cultures were diluted with fresh L1 medium at the same temperature before measurements were taken. Early observations showed that cell swimming speed was significantly reduced by the introduction of fresh medium. When dilutions were necessary they were therefore made at least $24 \mathrm{~h}$ before swimming speed was measured.

In a separate experiment, cells of $A$. tamarense (SB50) were incubated at $16^{\circ} \mathrm{C}$ under a photon flux density of $180-200$ $\mu \mathrm{mol}$ photons $\mathrm{m}^{-2} \mathrm{~s}^{-1}$ until the culture achieved exponential growth. The swimming speed of single cells was then compared with that of doublets and four-cell chains.

Details on DIH microscopy and a thorough discussion of its history and potential have been presented in a number of publications (Kreuzer et al. 2001, 2003; Xu et al. 2001, 2002, 2003), together with earlier results in biology and microfluidics. A schematic of the DIH microscope, in its current application, is shown in Fig. 1. A $\times 100$ microscope objective is used to focus light from a $3 \mathrm{~mW}$ solid-state laser with a wavelength of $473 \mathrm{~nm}$ onto a $1 \mu \mathrm{m}$ pinhole, which acts as the point source from which a spherical wave of wavelength $\lambda$ emanates. The wave illuminates an object and forms a geometrically magnified diffraction pattern on a CCD chip, a few centimetres away. If the scattered wave from the object is small compared with the unscattered reference wave, the interference pattern on the screen constitutes a hologram. Numerical reconstruction of the three-dimensional structure is achieved with a Kirchhoff-Helmholtz transform (Gabor 1949; Kreuzer et al. 2001), which has been implemented using the LEEPS

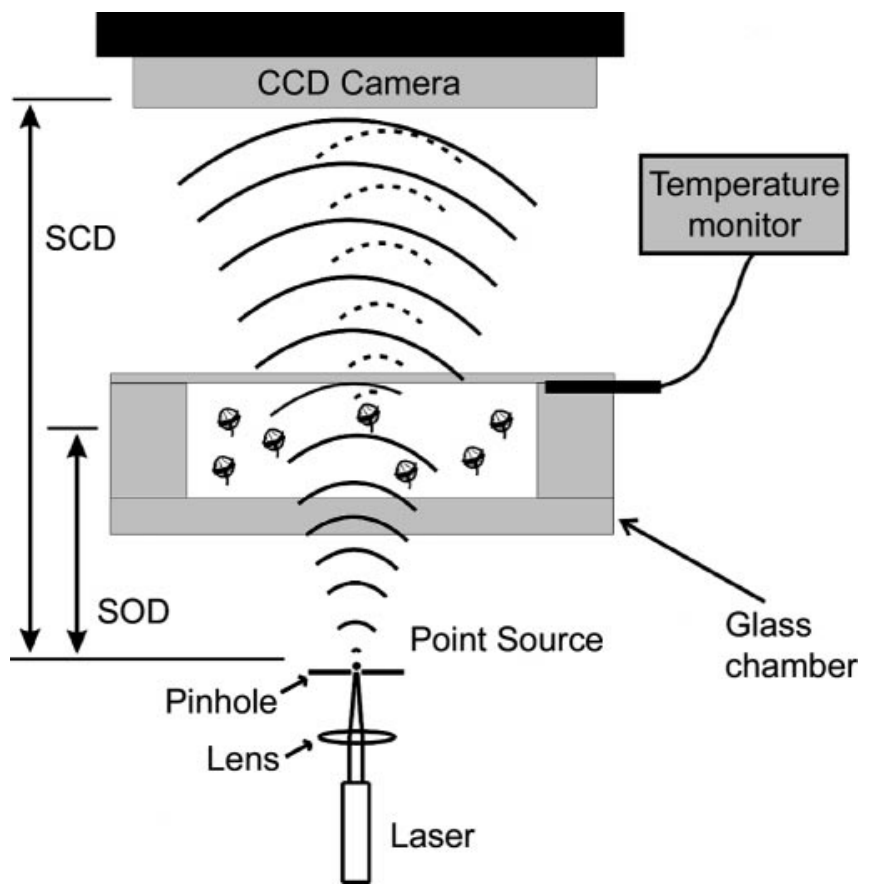

Fig. 1. Schematic drawing of the experimental apparatus. Laser light is focussed onto a pinhole that then acts as a point source for spherical waves that illuminate the algal sample. The light scattered by the algae (dotted wave fronts) combines with the unscattered light (solid wave fronts) to form an interference pattern, or hologram, on the CCD camera chip. The source-object distance (SOD) is generally much smaller than the source-screen distance (SSD), which leads to a magnification of the interference pattern. Sample temperature was monitored with a thermocouple.

software developed by Kreuzer \& Pawlitzek (1993), originally applied to electron holography.

The DIH microscope has an exceptionally large depth of field that depends in a complex way on the experimental parameters such as object-CCD chip and pinhole-CCD chip distances. For the conditions used in these experiments, the depth of field was $5 \mathrm{~mm}$. This large depth of field allows imaging throughout the sample volume with micron resolution. As a consequence, the three-dimensional trajectories of many algal cells can be obtained simultaneously. Time and space resolution are essentially determined by the capture rate and chip size of the CCD camera (Megaplus ES:1.0/MV CCD camera equipped with a CCD chip with a 1008 by 1018 array of 9 $\mu \mathrm{m}$ square pixels; the shortest exposure time was $0.13 \mathrm{~ms}$ and the fastest frame rate was 15 frames $\mathrm{s}^{-1}$ ). Multiple exposure imaging yields the complete trajectories, i.e. images of cells at different times, typically in a sequence of fixed time intervals (Xu et al. 2003).

The distance between two sequential positions of a cell in the same horizontal plane is measured digitally from one cell midpoint pixel to the next and the elapsed time between the two positions is used to calculate the velocity. This process is repeated 2-3 times along linear sections of the trajectory to give a mean speed for each cell.

\section{Data analysis}

Statistical analyses were performed using SigmaStat, V.2.03, SPSS Science software. Normality of each group was visually 

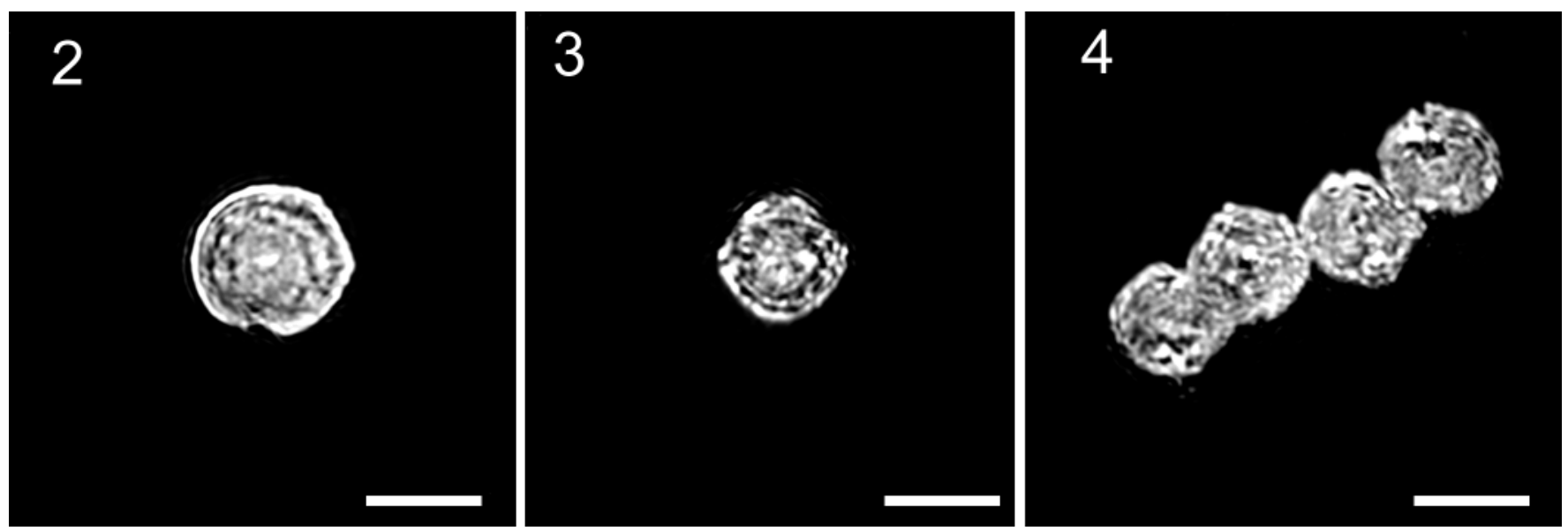

Figs 2-4. Reconstructed images of Alexandrium species. Hologram exposure time for all images was $60 \mathrm{~ms}$. Source to CCD chip distance $=$ $1.75 \mathrm{~cm}$ and source to sample distance $=1 \mathrm{~mm}$. Laser wavelength $=473 \mathrm{~nm}$. Scale bars $=30 \mu \mathrm{m}$.

Fig. 2. Alexandrium ostenfeldii at $12^{\circ} \mathrm{C}$.

Fig. 3. A single cell of $A$. tamarense.

Fig. 4. A four-cell chain of A. tamarense.

accessed from histograms and confirmed with the Kolmogorov-Smirnov test. In several cases, specifically, when the normality assumption was not met, a square root transformation was performed on the data. Homoscedasticity of variance was verified using Cochran's test for homogeneity of variance. Cells were randomly chosen, ensuring that the independence requirement was met, and permitting a one-way analysis of variance (ANOVA) on swimming speed. An ANOVA was also performed on maximum cell concentration as inferred from the fluorescence data. When differences in means were found to be statistically significant, Tukey's post hoc test for all pairwise comparisons was performed. A Student's $t$ test for independent samples was applied to test for differences between the means of two populations.

\section{RESULTS}

Under a growth-permissive temperature regime, A. minutum typically grows faster and reaches higher maximal cell concentrations ( 70 by $10^{3}$ cells $\mathrm{ml}^{-1}$ ) than does A. tamarense (20 by $10^{3} \mathrm{ml}^{-1}$ ) or $A$. ostenfeldii $\left(20\right.$ by $10^{3} \mathrm{ml}^{-1}$ ) (N. Lewis, unpublished data). Growth rate and cell concentration (as measured by in vivo fluorescence) of the three species of $\mathrm{Al}$ exandrium were directly affected by temperature. Maximum cell concentration of $A$. minutum occurred at $24^{\circ} \mathrm{C}$, after 17 days of growth, but was not significantly higher than at $20^{\circ} \mathrm{C}$ or at $16^{\circ} \mathrm{C}\left(P<0.001, F_{4,10}=13\right.$, Tukey's post hoc, $P<$ 0.05). Exponential growth of this isolate was not observed at temperatures below $16^{\circ} \mathrm{C}$.

Initially A. tamarense grew faster at $20^{\circ} \mathrm{C}$, but these cultures reached stationary phase after only 17 days, whereas at $16^{\circ} \mathrm{C}$ exponential growth continued for 12 days and the final cell concentration was significantly higher than at $20^{\circ} \mathrm{C}(P<$ 0.001, $F_{4,10}=46$, Tukey's post hoc, $\left.P<0.05\right)$. Cells appear to grow slightly slower at $12^{\circ} \mathrm{C}$ than at $16^{\circ} \mathrm{C}$ but this difference was not significant. There was no difference in maximum cell concentration at $12^{\circ} \mathrm{C}$ and $20^{\circ} \mathrm{C}$. Cultures incubated at $8^{\circ} \mathrm{C}$ did not die, but showed very little increase in cell number. Cul- tures tolerated $24^{\circ} \mathrm{C}$ for nine days but after that time, a decline in viable cells resulted in lowered fluorescence.

Alexandrium ostenfeldii grew much more slowly than the other two species, at all temperatures. Maximum cell concentration as determined by fluorescence after 17 days incubation was statistically higher at $16^{\circ} \mathrm{C}$ than at all other temperatures $\left(P<0.001, F_{4,10}=51\right.$, Tukey's post hoc, $\left.P<0.05\right)$. There was no significant difference in growth at 8 and $12^{\circ} \mathrm{C}$ or at 8 and $20^{\circ} \mathrm{C}$. Cells formed pellicular cysts after several days at $24^{\circ} \mathrm{C}$, and these continued to fluoresce at very low levels.

\section{Swimming behaviour and velocities}

DIH microscopy allows the acquisition of magnified threedimensional images of objects and of the trajectories of their motion. Images of Alexandrium cells shown in Figs 2-4 demonstrate the quality and resolution of DIH microscopy. The quality of these images is comparable to that of images obtained with conventional compound microscopy, but DIH microscopy has the additional advantage that the three-dimensional structure can be obtained from a single hologram (Xu et al. 2001). A series of 14 holograms (each containing only one image of the cell in each trajectory) were combined into one final hologram which is reconstructed in two different planes $(0.17 \mathrm{~mm}$ apart) in Figs 5 and 6 . The multiple exposures were taken at 2.5 frames s${ }^{-1}$, with exposure times of 20 ms. Each string of 'disks' belongs to a particular cell and adjacent 'disks' are the positions of the same cell $0.4 \mathrm{~s}$ apart. The arrowheads indicate the point at which that cell crosses this particular plane of the reconstruction. Constructing many such planes (from the same holographic sequence) will give the trajectories in three-dimensional space. Figs 7-10 show typical trajectories at different temperatures for both single cells and doublets. To obtain the swimming velocities, the distance between adjacent positions along a given trajectory was measured and multiplied by the frame rate. The results are summarized in Fig. 11 for the three species of Alexandrium at five temperatures.

Statistically significant differences in swimming speed were 

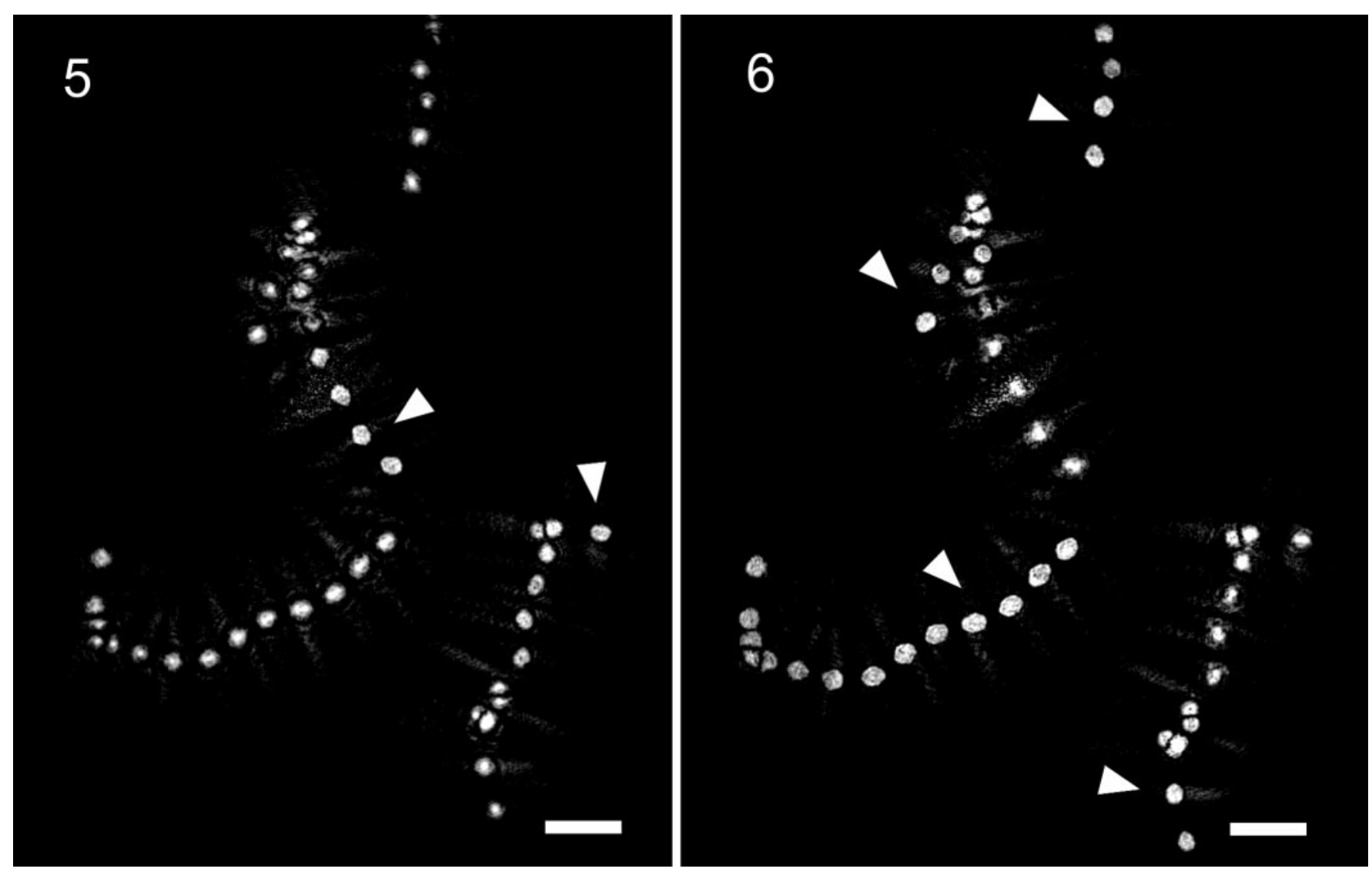

Figs 5, 6. Reconstructions of the trajectory of A. minutum cells in seawater at room temperature at two different planes of focus. The reconstruction planes in the images are $0.17 \mathrm{~mm}$ apart. Multiple holographic imaging of a sample volume thus allows the recording, as a single data set, of the history of the particle distribution within it. (laser wavelength $=473 \mathrm{~nm}$, exposure time $=20 \mathrm{~ms}$, frame rate $=2.5$ frames $\mathrm{s}^{-1}$ ). Scale bars $=100 \mu \mathrm{m}$. Arrowheads point to the algal cells in focus.

found for each isolate and the mean and range of speeds at each temperature are summarized in Table 1. The maximum recorded swimming speed was $474 \mu \mathrm{m} \mathrm{s}^{-1}$ for $A$. minutum incubated at $24^{\circ} \mathrm{C}$, while in contrast, the slowest speed for this species was $40 \mu \mathrm{m} \mathrm{s}{ }^{-1}$, observed at $12^{\circ} \mathrm{C}$. At 16 and $20^{\circ} \mathrm{C}$, swimming speeds were reduced to half that observed at $24^{\circ} \mathrm{C}$, but were not significantly different at these two lower temperatures. Swimming speeds were slowest at 8 and $12^{\circ} \mathrm{C}(P$ $<0.001, F_{4.146}=83$, Tukey's post hoc, $P<0.05$ ).

The fastest swimming speed recorded for $A$. tamarense, 406 $\mu \mathrm{m} \mathrm{s}^{-1}$, also occurred at $24^{\circ} \mathrm{C}$ and was significantly faster than that observed at $16^{\circ} \mathrm{C}$. Swimming speeds were slower at 20 , 12 and $8^{\circ} \mathrm{C}$ than at $16^{\circ} \mathrm{C}$ and there was no statistical difference among these temperatures $\left(P<0.001, F_{4,108}=33\right.$, Tukey's post hoc, $P<0.05)$.

Cells of $A$. ostenfeldii were the slowest swimmers among the three isolates, ranging in speed from $29 \mu \mathrm{m} \mathrm{s}^{-1}$ observed at $8^{\circ} \mathrm{C}$ to a maximum of $227 \mu \mathrm{m} \mathrm{s}^{-1}$ at $16^{\circ} \mathrm{C}$ (Table 1 ). The mean swimming speed of this species was significantly higher at $16^{\circ} \mathrm{C}$ than at the lower temperatures. There was no difference in the mean speed at 8 and $20^{\circ} \mathrm{C}(P=0.98)$, but movement was significantly slower at $12^{\circ} \mathrm{C}\left(P<0.001, F_{3,82}=27\right.$, Tukey's post hoc, $P<0.05)$.

Alexandrium ostenfeldii exhibited a peculiar pattern of circular swimming at $20^{\circ} \mathrm{C}$ (Fig. 10) that was not observed at any other temperature. Circular swimming was also observed in cells of A. tamarense when the experimental chamber became overheated by leaving the sample too long in the chamber.

Significant differences were also found in the swimming rates of the three isolates at each temperature. At lower temperatures, A. tamarense cells swam faster than the other two species studied (Fig. 11), but this difference was not significant at $8^{\circ} \mathrm{C}$, at which temperature there was no difference in speed among species $\left(P=0.096, F_{2,84}=2.4\right)$. At $20^{\circ} \mathrm{C}, A$. minutum swam significantly faster than $A$. ostenfeldii and $A$. tamarense $\left(P<0.001, F_{2,102}=10\right.$, Tukey's post hoc, $P<$ 0.002). After two days of acclimation at $24^{\circ} \mathrm{C}$, cells of $A$. ostenfeldii were no longer motile and $A$. tamarense swam significantly slower than $A$. minutum $(t=2.8$, df $=48, P=$ 0.008) (Fig. 11). Examination at $\times 400$ magnification revealed A. ostenfeldii cells had lost their theca and had formed pellicular cysts. Cyst formation was confirmed using an rRNA-targeted nucleic acid probe with fluorescent in situ hybridization (FISH) specific for A. ostenfeldii (John et al. 2003). When subjected to this probe, A. ostenfeldii cells fluoresce green when exposed to UV light, but pellicular cysts appear to be impermeable to the oligonucleotide probe (Rafuse 2004).

\section{Effect of growth phase on swimming speed of Alexandrium minutum}

After 23 days of growth at $24^{\circ} \mathrm{C}$, cultures of $A$. minutum had entered stationary phase; senescence as indicated by decreased 


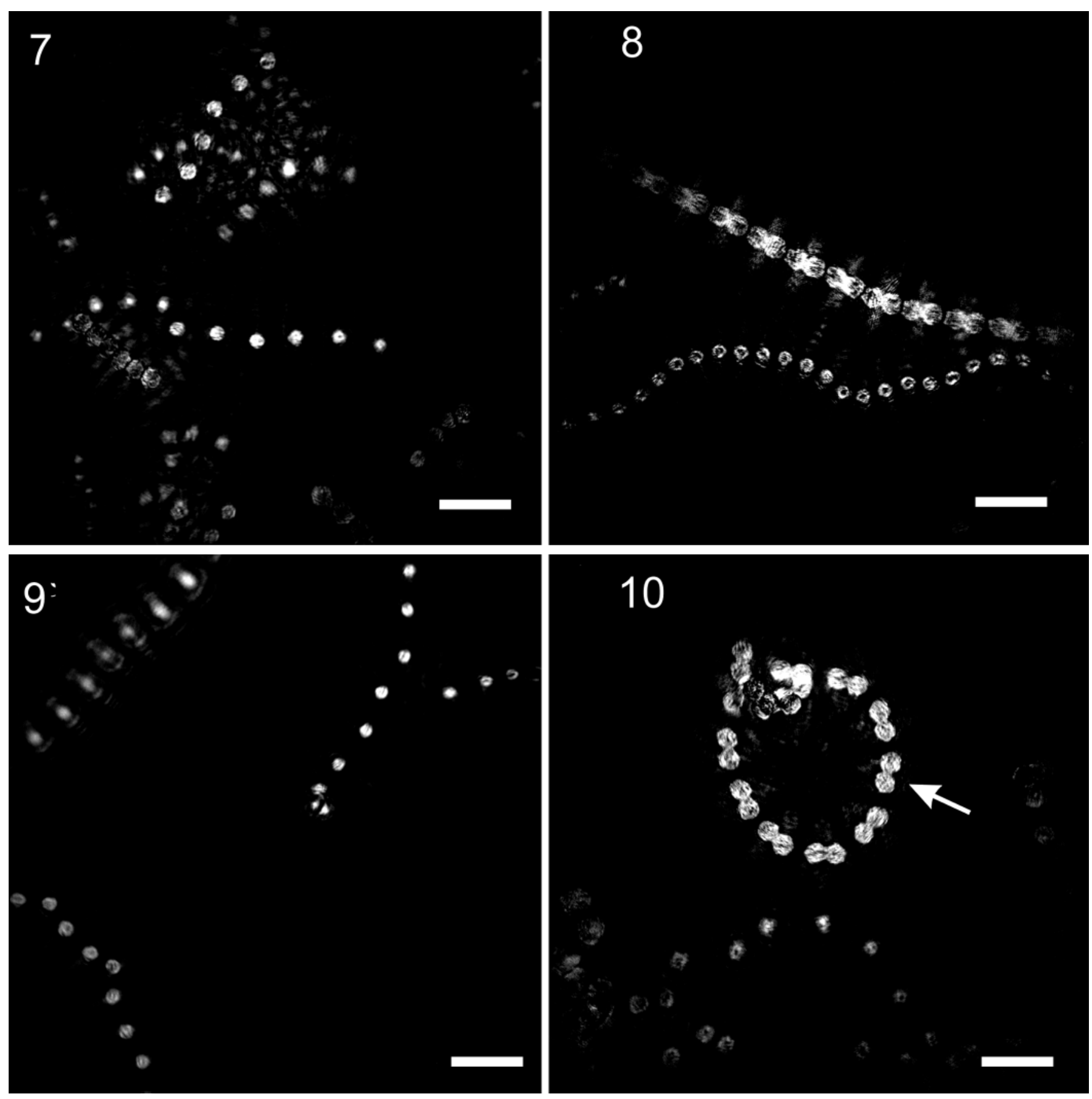

Figs 7-10. Reconstructions of algal trajectories at four temperatures. Scale bars $=100 \mu \mathrm{m}$.

Fig. 7. Alexandrium minutum at $8^{\circ} \mathrm{C}$. Time interval between successive cell positions is $0.28 \mathrm{~s}$.

Fig. 8. Alexandrium tamarense at $16^{\circ} \mathrm{C}$. The trajectories of both a single cell and a doublet are shown. Time interval between successive cell positions is $0.33 \mathrm{~s}$.

Fig. 9. Alexandrium minutum at $24^{\circ} \mathrm{C}$. Time interval between successive algae positions is $0.14 \mathrm{~s}$.

Fig. 10. Alexandrium tamarense at $20^{\circ} \mathrm{C}$, showing unusual pattern of circular swimming. Time interval between successive algae positions is $0.68 \mathrm{~s}$.

fluorescence, apparent mortality and shedding of thecae began one week later. Although there were still many motile cells after 32 days at this temperature, in vivo fluorescence had dropped significantly and a Student's $t$ test showed the mean swimming speed $\left(102 \pm 19 \mu \mathrm{m} \mathrm{s}^{-1}, n=12\right)$ was significantly lower $(t=8.8$, df $=36, P<0.001)$ than that measured for cells in early- to midexponential growth phase $(320 \pm 84 \mu \mathrm{m}$ $\left.\mathrm{s}^{-1} n=26\right)$. Cultures of this isolate grew much more slowly at $8^{\circ} \mathrm{C}$ and never exhibited exponential growth. The mean swimming speed of cells from a 32 day old culture at this temperature was $120 \pm 40 \mu \mathrm{m} \mathrm{s}^{-1}(n=26)$, which was not significantly different $(t=1.4$, df $=50, P=0.177)$ from the 


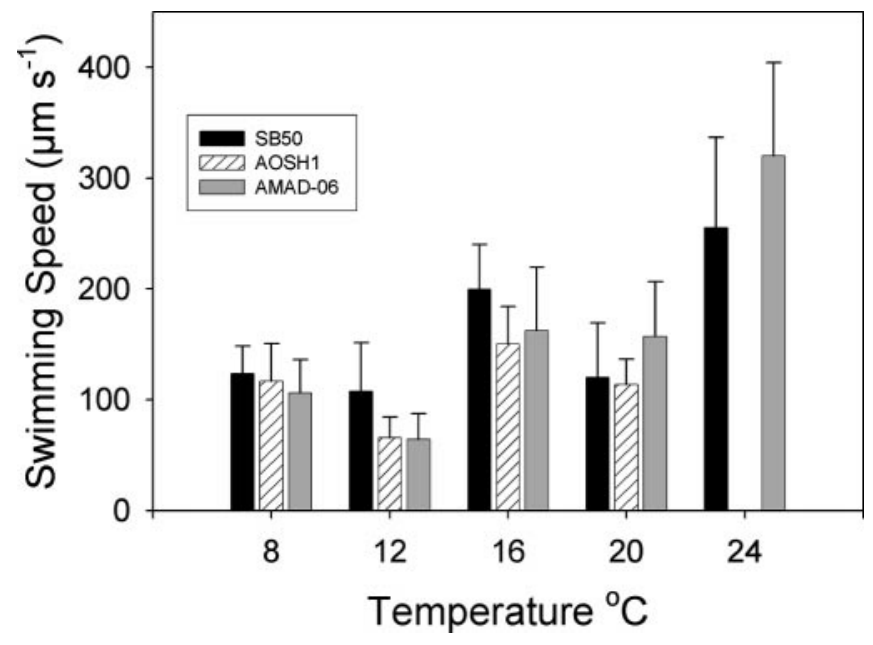

Fig. 11. Mean swimming speeds of single cells of three species of Alexandrium at five temperatures. Each point is a mean of two or three measurements of velocity calculated along the trajectory of one cell at a point when movement is linear two to three days after incubation at each temperature. Error bars indicate standard deviation. Cells of A. ostenfeldii were no longer motile after two days of exposure to $24^{\circ} \mathrm{C}$.

mean swimming speed recorded for cells 10 days after inoculation $\left(106 \pm 30 \mu \mathrm{m} \mathrm{s}^{-1}, n=26\right)$ when incubated at $8^{\circ} \mathrm{C}$ for $48 \mathrm{~h}$.

\section{Comparison of swimming speed of single cells vs chains of A. tamarense}

Swimming speeds for single cells of A. tamarense ranged from 82 to $372 \mu \mathrm{m} \mathrm{s}^{-1}$, while the range of swimming speeds for doublets was 238 to $472 \mu \mathrm{m} \mathrm{s}^{-1}$ (Table 2). A Student's $t$ test showed that single cells $\left(238 \pm 64 \mu \mathrm{m} \mathrm{s} \mathrm{s}^{-1}, n=156\right)$ swam significantly slower $(t=14$, df $=265, P<0.001)$ than doublets $(344 \pm 51, n=111)$. Although three- and four-cell chains occurred frequently in the culture, they proved to be very difficult to find under the microscope. It is possible that these delicate chains were broken while being transferred by pipette to the sample chamber. We were only able to find and measure the speed of three chains of four cells, which swam on average much more slowly $\left(166 \pm 33 \mu \mathrm{m} \mathrm{s}^{-1} ; n=3\right)$ than either doublets or single cells.

\section{DISCUSSION}

Growth comparisons among cultures grown at different temperatures, as determined by in vivo fluorescence, must be interpreted cautiously because of the temperature-dependence of emitted fluorescence and the differential effects of temperature on growth rates. We have, therefore, only used fluorescence data to track growth within a batch culture at a given temperature, as an index of relative cell concentration, and thus of growth stage in culture.

We were not surprised to find that optimum growth in the three species, isolated from different environments, occurred at different temperatures. The isolate of $A$. minutum (AMAD06) was collected from the sediments of the Port River, South Australia, where temperatures in the water column range from
Table 2. The mean $( \pm s)$ and range of swimming speeds for single cells and doublets of Alexandrium tamarense, isolate SB50. Drag forces approximated by considering the doublets as both an equivalent sphere and as two equal spheres in contact.

\begin{tabular}{|c|c|c|}
\hline & $\begin{array}{l}\text { Swimming speed } \\
\qquad\left(\mu \mathrm{m} \mathrm{s}^{-1}\right)\end{array}$ & $\begin{array}{c}\text { Force }^{1} \\
(\mathrm{pN})\end{array}$ \\
\hline Single $(\bar{x} \pm s)$ & $238 \pm 64(n=156)$ & 66 \\
\hline Single (maximum) & 360 & 101 \\
\hline Doublet $(\bar{x} \pm s)$ & $344 \pm 52(n=111)$ & 124 \\
\hline Doublet (maximum) & 472 & 170 \\
\hline $\begin{array}{l}\text { Doublet }(\bar{x} \pm s) \text { (equivalent } \\
\text { sphere) }\end{array}$ & & 121 \\
\hline $\begin{array}{l}\text { Doublet (maximum) (equiv- } \\
\text { alent sphere) }\end{array}$ & & 166 \\
\hline
\end{tabular}

$10^{\circ} \mathrm{C}$ in winter to $25^{\circ} \mathrm{C}$ in summer, with higher temperatures occasionally occurring in embayments. Blooms of this species generally occur in spring or fall when the water temperature ranges from 14 to $19^{\circ} \mathrm{C}$ (Cannon 1993a). In an earlier study, Cannon (1993b), determined that optimum growth of this isolate of $A$. minutum in culture occurred at $16^{\circ} \mathrm{C}$ at a photon flux density of $100 \mu \mathrm{mol}$ photons $\mathrm{m}^{-2} \mathrm{~s}^{-1}$. In our experiments, optimum growth of $A$. minutum (AMAD-06) occurred at $24^{\circ} \mathrm{C}$ but maximum cell concentration was not significantly different than at 16 or $20^{\circ} \mathrm{C}$. We used a different nutrient medium in our experiments and the photon flux density $(125-150 \mu \mathrm{mol}$ photons $\mathrm{m}^{-2} \mathrm{~s}^{-1}$ ) was higher than in the previous study. Nevertheless, this species grew quite well at $16^{\circ} \mathrm{C}$ and motility was not significantly different from that at $20^{\circ} \mathrm{C}(P<0.05)$.

The isolate of Alexandrium ostenfeldii (AOSH1) used for these experiments grows very slowly and tolerates a relatively narrow range of temperature compared to A. tamarense and A. minutum. Optimum growth occurred at $16^{\circ} \mathrm{C}$, the same temperature at which maximum swimming speed was observed. Alexandrium ostenfeldii consistently swims slower than A. tamarense, although this difference was significant only at 16 and $12^{\circ} \mathrm{C}$. These laboratory observations from cultures are consistent with the swimming behaviour of cells of both species in field samples freshly collected during the early spring in Nova Scotia, when water temperatures are between 10 and $12^{\circ} \mathrm{C}$. It can be difficult to morphologically distinguish smaller A. ostenfeldii cells from A. tamarense at low magnification, but their different swimming behaviour makes it easier to identify the more lethargic A. ostenfeldii cells in a plankton sample. Isolates of this species, including AOSH1, grow well initially at $16^{\circ} \mathrm{C}$, but often eventually die at this temperature, indicating that this represents an upper temperature tolerance limit. This species is not usually found in field samples from Nova Scotia when the ambient surface water temperature exceeds $16^{\circ} \mathrm{C}$ for a substantial time (a few days).

Alexandrium tamarense (SB50), adapted to the colder waters of Nova Scotia, grew well at temperatures from 12 to $20^{\circ} \mathrm{C}$, with optimum growth at $16^{\circ} \mathrm{C}$. This species occurs in early to midsummer in Nova Scotia, when water temperatures are usually in this range, and forms blooms when environmental conditions are optimum.

Growth temperature has an effect on the swimming speeds of isolates of different species of Alexandrium. As Kamykowski \& McCollum (1986) observed, swimming ability can 
be maintained over a wider temperature range than that over which growth occurs. In an earlier preliminary study (Lewis et al. 2003), it was reported that the highest rates of swimming for each of the Alexandrium isolates studied occurred at the temperature at which optimum growth was observed. However, further analysis of swimming speeds in cultures acclimated to high temperatures showed that although cells of SB50 were capable of swimming significantly faster at $24^{\circ} \mathrm{C}$, growth of SB50 was least favourable at this temperature (Table 1).

The swimming speed of $A$. minutum (AMAD-06) cells at $24^{\circ} \mathrm{C}$ in stationary phase $\left(102 \pm 19 \mu \mathrm{m} \mathrm{s}^{-1}\right)$ was lower compared to cells in exponential growth phase $\left(320 \pm 84 \mu \mathrm{m} \mathrm{s}^{-1}\right)$. There was no significant reduction in speed in the older culture at $8^{\circ} \mathrm{C}$. After 32 days of growth at $24^{\circ} \mathrm{C}$ cells ceased dividing and the culture became senescent. In contrast, cells of this isolate did not go into stationary phase at $8^{\circ} \mathrm{C}$ and continued to divide after five weeks at this temperature. Thus, the physiological status or growth phase of the culture may be a more important determinant of growth than the chronological time in culture. This further suggests that growth phase may predominate over temperature as a predictor of swimming velocity and behaviour. Much slower swimming as expected in cultures in stationary phase may also be a feature of senescent blooms of natural populations.

Circular swimming was only observed when cells appeared to be under thermal stress such as exhibited by A. ostenfeldii at $20^{\circ} \mathrm{C}$, and was not observed when cells were incubated at lower temperatures. This peculiar swimming behaviour was also observed for A. tamarense when the chamber temperature rose high enough for the cells to experience thermal shock. Iken et al. (2001) observed abnormal or 'circular' swimming in the spores of the heterokont Hincksia irregularis, but attributed this to the detection of physical and chemical gradients within a microhabitat. They also described a rare 'wobbling' swimming phenomenon that they suggested was due to damaged flagella. By limiting the time cells were in the test chamber to less than 10 minutes, we were able to minimize thermal stress that would affect the swimming behaviour of the cells. In Alexandrium spp., sudden thermal shocks may result in rapid cell death at elevated temperatures, whereas a rapid 'shift-down' can cause loss of motility and sedimentation of cells because of the formation of pellicular cysts and consequent loss of the flagella and thecae (A.D. Cembella, personal observation). Cells could be exposed to rapid changes in temperature either during diel vertical migration, when aggregated into thin layers that are suddenly dispersed or during tidal and wind dominated mixing events in coastal embayments and estuaries. Thermal shock would likely cause loss of motility by formation of ecdysal cysts, which would then sink.

Different maximum swimming speeds would be expected for species that differ in cell size and morphology. Kamykowski \& McCollum (1986) suggested that swimming speed increased with the length of the cell up to about $35 \mu \mathrm{m}$ and then decreased as size increased, as was observed in this study (Table 1). In addition to environmental parameters, the morphology of the cell and the flagellar arrangement also affect swimming speed and behaviour (Roberts 1981). For the three species of Alexandrium studied here, all with the same shape, the decrease in swimming speed with size was most likely due to the increased drag on the larger isolates.
Fraga et al. (1989) showed that swimming velocity in Gymnodinium catenatum Graham and Alexandrium affine Inoue and Fukuyo increased with the number of cells in the chain, although the increase in velocity was greatest for short chains of two to four cells. Although A. tamarense does not produce long chains of cells, as do some species of Alexandrium, such as A. catenella, doublets are commonly found both in naturally occurring blooms and in cultures. Under casual visual microscopic observation, these doublets appear to swim much faster than single cells. More rarely, slower moving chains of three or four cells are also observed. DIH holography has confirmed the advantage in swimming rate of paired cells ('doublets') within a given species at a defined temperature. Fraga et al. (1989) suggest that the advantage of swimming in a chain is greater at high temperatures, however we did not look at the swimming speed of doublets at higher temperatures.

To understand the increase in swimming speed when microalgal cells are paired, the changes in propulsion and drag must be compared. A single algal cell (e.g. of Alexandrium) may be approximated as a sphere and a doublet as two spheres attached to each other. Stokes derived the drag force, F, on a sphere of diameter $\mathrm{d}$, moving with a velocity $\mathrm{V}$ through a liquid of viscosity $\eta$ :

$$
\mathrm{F}=3 \pi \eta \mathrm{dV} \lambda
$$

with $\lambda=1$ for a sphere, where $\lambda$ is a dimensionless parameter that allows for deviations of the object from a spherical shape. This force, in the opposite direction, is also required for the propulsion of the sphere. The motion of two spheres in a viscous medium was treated analytically by Stimson \& Jeffrey (1926). We estimate from their solutions that, for two equal spheres in contact and moving parallel to their line of centres, $\lambda=1.292$.

The drag force on objects with nonspherical shapes can also be approximated by considering the nonspherical object as a sphere that has the same volume. For the case of two spheres of diameter $\mathrm{d}$ in contact, the diameter of the equivalent sphere $d_{e}$ is given by $d_{e}=(2)^{1 / 3} d$.

The drag forces on cells (shown in Table 2), for a viscosity $\eta=0.00111 \mathrm{Ns} \mathrm{m}^{-2}$ and a cell diameter of $26.7 \pm 2.6 ; \mu \mathrm{m}$ ( $n=30$ ), can be summarized by the following expressions:

$$
\begin{aligned}
\text { single cell } \mathrm{F}_{\mathrm{s}} & =3 \pi \eta \mathrm{dV} \\
\text { doublet } \mathrm{F}_{\mathrm{D}} & =3 \pi \eta \mathrm{dV \lambda} \\
\text { doublet (equivalent sphere) } \mathrm{F}_{\mathrm{DE}} & =3 \pi \eta d_{\mathrm{e}} \mathrm{V}
\end{aligned}
$$

Note that the drag force approximated by considering the doublets as an equivalent sphere is very close to that calculated for two equal spheres in contact (Table 2). The forces exerted by a doublet are 1.88 and 1.68 times larger than those for a single cell for the mean and maximum velocities. If only one member of the pair were active and applied a force equal to that of a single cell, then the pair speed would be $\mathrm{V}_{\text {single }} / \lambda$. For the above data, this would imply an average doublet speed of $188 \mu \mathrm{m} \mathrm{s}^{-1}$. However, the mean swimming speed for doublets was $344 \pm 52 \mathrm{~s}^{-1}(n=111)$ and the lowest swimming speed observed was $238 \mu \mathrm{m} \mathrm{s}^{-1}$, indicating that both cells in a doublet are active in propulsion. The observation that the double/single force ratio for the maximum speed is consid- 
erably less than 2 could simply mean that faster swimming pairs were present but we missed detecting them. Another possible explanation is that the enhancement is less at the maximum speed because it is less likely that both cells in the doublet are at their maximum performance.

There are always concerns when observations made in the laboratory are extrapolated to the natural environment. The small volume chambers required to obtain the high resolution of the holographic microscope may cause subtle hydrodynamic effects on swimming that are not accounted for in these experiments. Kamykowski \& McCollum (1986) also ignored any potential hydrodynamic effects when measuring swimming rates of cells swimming near the wall of the cuvette. For our experiment, the minimum scaling of depth to the largest cell length was $24: 1$. Any effects on swimming behaviour due to this small volume are reduced by minimizing the temporal and spatial interval over which measurements are made. Swimming behaviour appeared to be normal as compared to that observed under the light microscope, and we saw no avoidance response in the cells, such as described by Levandowsky \& Kaneta (1987). Swimming speeds measured using the holographic techniques are consistent with those previously reported for dinoflagellates (Hand et al. 1965; Kamykowski \& McCollum 1986), and in any case, wall effects should have little effect on measurements of relative velocity among these isolates.

Light shock is also an important potential artefact to be considered in measurements of swimming velocity. For these experiments, we used a $3 \mathrm{~mW}$ solid-state laser with a wavelength of $473 \mathrm{~nm}$, although lasers of different wavelengths may be used in DIH microscopy. The maximum photon flux density the algae were exposed to when they are closest to the pinhole was $160 \mu \mathrm{mol}$ photons $\mathrm{m}^{-2} \mathrm{~s}^{-1}$. The intensity remains constant with different fields of view, but decreases as the cells move away from the pinhole. Cells swimming away from the pinhole would be subjected to a photon flux density roughly equal to the $125 \mu \mathrm{mol}$ photons $\mathrm{m}^{-2} \mathrm{~s}^{-1}$ at which they were acclimated.

Although little is known about the effects of light of different wavelengths on dinoflagellate swimming behaviour, Watanabe \& Furuya (1974) showed that swimming rates of the cryptomonad Cryptomonas sp. remained unchanged when cells were exposed to light of various wavelengths, including blue light $(490 \mathrm{~nm})$. For most flagellates, the action spectrum of phototaxis peaks in the blue and green part of the spectrum (Haldall 1958). Lombard \& Capon (1971) found that cells of the daytime migrating dinoflagellate, Peridinium gregarium Lombard, were activated by blue light $(457 \mathrm{~nm})$ but did not swim toward it. The evidence suggests that the effects of exposure to blue light on swimming speed and behaviour is minimal on algal cells. In any event, such potential effects would be reduced by the short time the cells are exposed to the light.

DIH microscopy is a powerful new tool for the study of biological systems, including investigations of bacterial attachment to surfaces (biofilms), remote sensing and environmental monitoring, and particle velocimetry, i.e. tracking the motion of particles in liquid or gas flow.

In the latter application, we found that DIH microscopy is an elegant method for studying motility in microalgal cells. The acquisition of high-resolution images of a cell through an exceptionally large depth of field makes it possible to track movement of motile cells in three-dimensional space. The system is simple, consisting of only a laser, pinhole and a CCD camera. A single hologram contains all of the information about the three-dimensional structure of the object. Reconstruction of a sequence of holographic images permits the tracking of an object through time and space. Optimum resolution of the order of the wavelength of the laser can be obtained easily.

Most importantly, it is possible to study living cells in a nondestructive manner. In the present experiments, performed under temperature-controlled conditions in the laboratory, we have shown that the temperature effects on swimming behaviour are species-specific and can be markedly affected by the temperature at which they have been preconditioned. Cell physiological status and 'age' of the culture are also important determinants of swimming velocity. Future experiments are envisaged using a submersible version of this DIH microscope as a tool to study the movement of plankton, organic particles, air bubbles etc., in the water column. In situ measurements of microalgal swimming behaviour will be an important contribution to our knowledge of bloom formation of motile species.

\section{ACKNOWLEDGEMENTS}

This work was supported by grants from NSERC and the Office of Naval Research. We appreciate the contribution of Cheryl Rafuse, NRC, in the application of molecular probes. We thank Dr Stephen Bates and Dr John Walter for their comments on the manuscript. One of the authors (A.C.) also acknowledges the cooperation of the Alfred-Wegener Institute in the preparation of the manuscript. This publication is NRC (Canada) No. 42527.

\section{REFERENCES}

ANDERSON D.M. 1998. Physiology and bloom dynamics of toxic $\mathrm{Al}$ exandrium species, with emphasis on life cycle transitions. In: Physiological ecology of harmful algal blooms (Ed. by D.M. Anderson, A.D. Cembella \& G.M. Hallegraeff), pp. 29-48. NATO-Advanced Study Institute Series, V. 41, Springer-Verlag, Heidelberg, Germany. CANNON J.A. 1993a. Germination of the toxic dinoflagellate Alexandrium minutum from the Port River, South Australia. In: Toxic phytoplankton blooms in the sea (Ed. by T.J. Smayda \& Y. Shimizu), pp. 103-107. Elsevier, Amsterdam.

CANNON J.A. 1993b. Growth in culture of the toxic dinoflagellate $A l$ exandrium minutum from the Port River, South Australia. In: Toxic phytoplankton blooms in the sea (Ed. by T.J. Smayda \& Y. Shimizu), pp. 741-745. Elsevier, Amsterdam.

Cembella A.D. 1998. Ecophysiology and metabolism of paralytic shellfish toxins in marine microalgae. In: Physiological ecology of harmful algal blooms (Ed. by D.M. Anderson, A.D. Cembella \& G.M. Hallegraeff), pp. 381-404. NATO-Advanced Study Institute Series, V. 41, Springer-Verlag, Heidelberg, Germany.

Eppley R.W., Holm-Hansen O. \& Strickland J.D.H. 1968. Some observations on the vertical migration of dinoflagellates. Journal of Phycology 4: 333-340.

ForwARD R.B. 1974. Phototaxis by the marine dinoflagellate Gymnodinium splendens Lebour. Journal of Protozoology 21: 312-315.

Fraga S., Gallager S.M. \& Anderson D.M. 1989. Chain-forming dinoflagellates: an adaptation to red tides. In: Red tides: biology, 
environmental science, and toxicology (Ed. by T. Okaichi, D.M. Anderson \& T. Nemoto), pp. 281-284. Elsevier, New York, USA.

GABOR D. 1949. Microscopy by reconstructed wavefronts. Proceedings of the Royal Society of London, Series A 197: 454-487.

GAINES G. \& TAYLOR F.J.R. 1985. Form and function of the dinoflagellate transverse flagellum. Journal of Protozoology 32: 290-296.

GoldSTEIN S.F. 1992. Flagellar beat patterns in algae. In: Algal cell motility (Ed. By M. Melkonian), pp. 99-153. Chapman \& Hall, New York, USA.

GuILlard R.R.L. \& HARGRAVES P.E. 1993. Strichochrysis immobilis is a diatom, not a chrysophyte. Phycologia 32: 234-236.

Haldall P. 1958. Action spectra of phototaxis and related problems in Volvocales, Ulva gametes and Dinophyceae. Physiologia Plantarum 11: 118-153.

HAND W.G. \& SchmidT J.A. 1975. Phototactic orientation by the marine dinoflagellate Gyrodinium dorsum Kofoid. II. Flagellar activity and overall response mechanisms. Journal of Protozoology 22: 494-498.

Hand W.G., Collard P.A. \& DavenPort D. 1965. The effects of temperature and salinity change on swimming rate in the dinoflagellates Gonyaulax and Gyrodinium. Biological Bulletin (Woods Hole) 128: 90-101.

Iken K., Amsler C.D., Greer S.P. \& McClintock J.B. 2001. Qualitative and quantitative studies of the swimming behaviour of Hincksia irregularis (Phaeophyceae) spores: ecological implications and parameters for quantitative swimming assays. Phycologia 40: 359366.

John U., Cembella A., Hummert C., Elbrächter M., Groben R. \& MedLIN L. 2003. Discrimination of the toxigenic dinoflagellates $A l$ exandrium tamarense and $A$. ostenfeldii in co-occurring natural populations from Scottish coastal waters. European Journal of Phycology 38: 25-40.

KAMYкоwski D. 1995. Trajectories of autotrophic marine dinoflagellates. Journal of Phycology 31: 200-208.

Kamykowski D. \& MCCollum S.A. 1986. The temperature acclimatized swimming speed of selected marine dinoflagellates. Journal of Plankton Research 8: 275-287.

Kamykowski D., Yamazaki H., TAmazaKi A.K. \& KirkPatrick G.J. 1998. A comparison of how different orientation behaviors influence dinoflagellate trajectories and photoresponses in turbulent water columns. In: Physiological ecology of harmful algal blooms (Ed. by D.M. Anderson, A.D. Cembella \& G.M. Hallegraeff), pp. 581599. NATO-Advanced Study Institute Series, v. 41, Springer-Verlag, Heidelberg, Germany.

Kreuzer H.J. \& PAwlitzeK R.A. 1993. LEEPS, Version 1.2. A software package for the simulation and reconstruction of low energy electron point source images and other holograms. Available from the authors at http://fizz.phys.dal.ca/ kreuzer/leeps.html.

Kreuzer H.J., Jericho M.H., Meinertzhagen I.A. \& Xu W. 2001. Digital in-line holography with photons and electrons. Journal of Physics: Condensed Matter 13: 10729-10741.

Kreuzer H.J., Jericho M.H., Meinertzhagen I.A. \& Xu W. 2003. Digital in-line holography with numerical reconstruction: 4D tracking of microstructures and organisms. SPIE Proceedings 5005-17: 299-306.
LEBLOND P.H. \& TAYLOR F.J.R. 1976. The propulsive mechanism of the dinoflagellate transverse flagellum reconsidered. Biosystems 8: 33-39.

Levandowsky M. \& Kaneta P.J. 1987. Behaviour in dinoflagellates. In: The biology of dinoflagellates (Ed. by F.J.R. Taylor), pp. 360397. Blackwell Scientific, Oxford, UK.

Lewis N.I., Cembella A.D., Xu W., Jericho S.K., Jericho M.H. \& KREUZER H.J. 2003. Effect of temperature on motility of three species of the marine dinoflagellate Alexandrium. In: Proceedings of the eighth Canadian workshop on harmful marine algae (Ed. by S.S. Bates), pp. 80-87. Canadian Technical Report of Fisheries and Aquatic Sciences No. 2948

LOMBARD E.H. \& CAPON B. 1971. Observations on the tidepool ecology and behavior of Peridinium gregarium. Journal of Phycology 7: $188-194$.

MacIntyre J., Cullen J.J. \& Cembella A.D. 1997. Vertical migration, nutrition and toxicity in the dinoflagellate Alexandrium tamarense. Marine Ecology Progress Series 148: 201-216.

Maclean C., Cembella A.D. \& Quilliam M.A. 2003. Effects of light, salinity and inorganic nitrogen on cell growth and spirolide production in the marine dinoflagellate Alexandrium ostenfeldii. Botanica Marina 46: 466-476.

Parkhill J.P. \& Cembella A.D. 1999. Effects of salinity, light and inorganic nitrogen on growth and toxigenicity of the marine dinoflagellate Alexandrium ostenfeldii from northeastern Canada. Journal of Plankton Research 21: 939-955.

RAFUSE C.M. 2004. Effects of physiological and environmental conditions on rRNA probes for two species of microalgae Alexandrium ostenfeldii and A. tamarense. MSc thesis. Dalhousie University, Halifax, Nova Scotia, Canada.

RAVEN J.A. \& RiCHARDSON K. 1984. Dinophyte flagella: a cost-benefit analysis. New Phytology 98: 259-276.

RoBerTs A.M. 1981. Hydrodynamics of protozoan swimming. In: Biochemistry and physiology of protozoa, vol. 4. (Ed. by M. Levandowsky \& S.H. Hutner), pp. 5-66. Academic Press, New York, USA.

Stimson M. \& JefFrey G.B. 1926. The motion of two spheres in a viscous fluid. Proceedings of the Royal Society of London Series A 111: 110-116.

Watanabe M. \& Furuya M. 1974. Action spectrum of phototaxis in a cryptomonad alga Cryptomonas sp. Plant \& Cell Physiology 15: 413-420.

Xu W., Jericho M.H., Meinertzhagen I.A. \& Kreuzer H.J. 2001. Digital in-line holography for biological applications. Proceedings of the National Academy of Sciences USA 98: 11301-11305.

Xu W., Jericho M.H., Meinertzhagen I.A. \& Kreuzer H.J. 2002. Digital in-line holography of microspheres. Applied Optics 41: 5367-5375.

Xu W., Jericho M.H., Kreuzer H.J. \& Meinertshagen I.A. 2003. Tracking particles in four dimensions with in-line holographic microscopy. Optics Letters 28: 164-166.

Received 26 July 2004; accepted 12 July 2005

Communicating editor: $C$. Amsler 